\title{
EFFECT OF BEAN CULTIVARS ON SOIL MICROORGANISMS
}

\author{
Bojana Petrovićc , Simonida Đuriće ${ }^{2}$ Mirjana Vasićc \\ Vesna Tunguz ${ }^{4}$, Robert Pokluda ${ }^{1}$
}

\begin{abstract}
${ }^{1}$ Department of Vegetable Growing and Floriculture, Mendel University in Brno, Valtická 337, 69144 Lednice Czech Republic

${ }^{2}$ Department of Field and Vegetable Crops, University of Novi Sad, Faculty of Agriculture, Trg Dositeja Obradovića 8, 21000 Novi Sad, Serbia

${ }^{3}$ Department of Vegetable Crops, Institute of Field and Vegetable Crops, Maksima Gorkog 30, 21000 Novi Sad, Serbia ${ }^{4}$ Department of Soil and Water, University of East Sarajevo, Faculty of Agriculture, Vuka Karadžića bb, 71123 East Sarajevo, Bosnia and Herzegovina
\end{abstract}

\begin{abstract}
PETROVIĆ BOJANA, ĐURIĆ SIMONIDA, VASIĆ MIRJANA, TUNGUZ VESNA, POKLUDA ROBERT. 2018. Effect of Bean Cultivars on Soil Microorganisms. Acta Universitatis Agriculturae et Silviculturae Mendelianae Brunensis, 66(1): 0155-0160.

The aim of this study was to determine the microbiological activity in soil under beans in organic and conventional production. Organic production was conducted on the field in the village Pivnice (Serbia), while conventional production was conducted in the village Curug (Serbia) during 2014 on the chernosem type soil. Cultivars of beans Belko, Dvadesetica, Maksa, Slavonac, Sremac, Zlatko were used. Before sowing, the bean seeds were inoculated by biofertilizers NS-Nitragin. NS-Nitragin contains a mixture of selected strains of symbiotic bacteria Rhizobium leguminosarum bv. phaseoli. The total number of actinomycetes, ammonifiers, Azotobacter, bacteria and fungi were determined. At the end of vegetation period in conventional production the highest number of actinomycetes (5.83) and fungi (4.87) was recorded in cultivar Dvadesetica. In organic production the highest number of ammonifires was in cultivar Sremac (9.91). The highest number of bacteria was in cultivar Dvadesetica (9.08) and the highest number of fungi was in cultivar Zlatko (5.14).

The results have shown that number of microorganisms was higher in organic production.
\end{abstract}

Keywords: actinomycetes, ammonifires, Azotobacter, bacteria, fungi, Phaseolus vulgaris.

\section{INTRODUCTION}

Beans, due to the ability of forming nodules, can fix nitrogen from the atmosphere and thus they contain one or more types of microorganisms. Beans in association with Rhizobium can fix from 25 to $120 \mathrm{~kg}$ N/ha (Wani et al., 1994).

Compared to other legumes it is considered poor nitrogen fixation (Nleya et al., 2001), in the beginning of the growing season, until appearing lumps, application of small quantities of nitrogen fertilizers is necessary (George and Singleton, 1992).

The bacterias which lives in symbiosis with beans can use atmospheric nitrogen which is spent for the needs of growth and development of plants (Marinkovic, J. 2006).
During the season, depending on environmental conditions, legumes in association with rhizobacteria can fix up to $400 \mathrm{~kg} \mathrm{~N} / \mathrm{ha}$ (Wani et al., 1994). As aresult of nitrogen fixation during the growth and development of legumes, the share of fixed nitrogen in yield is $10-95 \%$ or $20-400 \mathrm{~kg} \mathrm{~N} /$ ha per. The number and activity of microorganisms can be considered as a significant indicator of potential and effective soil fertility (Bloem and Hopkins, 2006).

Changing the number of microorganisms that perform nitrogen fixation processes, aminofication, nitrification and other processes in the soil, it is often positively correlated with the yield of plants (Neeru and Vasudeva, 2007). In addition to the mineralization and the cycling of nutrients, soil microorganisms and mikrobivori are also involved 
in other important ecosystem functions, such as the formation and preservation of soil.

\section{MATERIALS AND METHODS}

The trial was established at two sites, production of beans in organic system in the experimental

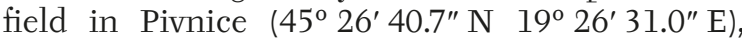
and production of beans in conventional system in the experimental field in Curug ( $45^{\circ} 25^{\prime} 18.9^{\prime \prime} \mathrm{N}$ $\left.20^{\circ} 03^{\prime} 16.1^{\prime \prime} \mathrm{E}\right)$ on the Chernosem soil type. The bean cultivars used in the trial were: Balkan, Belko, Dvadesetica, Maksa, Slavonac, Sremac and Zlatko developed at Institute of Field and Vegetable Crops in Novi Sad, Serbia. The experiment was set in 2014 according to the block system in four repetitions.

The seed beans were inoculated by the microbiological preparation NS-Nitragin (produced by the Institute of Field and Vegetable Crops, Novi Sad, Serbia). NS-Nitragin containing a mixture of selected strains of symbiotic bacteria Rhizobium leguminosarum bv. phaseoli.

Soil samples for microbiological analyzes were taken from the rhizosphere from a depth of 0.3-06 $\mathrm{m}$ and 0.6-0.9 m. At both sites, samples were taken from 7 different places on the plot. Samples for analysis were taken at the beginning of the growing season in May and the end of the season after the harvest in August. Determining of microbiological characteristics was performed in the laboratory of the Agriculture Faculty, University of Novi Sad, Serbia. Microbiological analysis determined total number of actinomycetes, ammonifiers, Azotobacter, bacteria and fungi.
Determination of the number off microorganisms was performed by the method of forming colonies on selective plates in three repetition (Jarak and Djuric, 2006). The number of microorganisms was converted per gram of absolutely dry soil, and the data were statistically analyzed.

Actinomycetes were determined by using method of Krasiljnikov solid medium $\left(10^{4}\right)$, (Krasiljnikov 1965), number of ammonifiers on MPA medium $\left(10^{7}\right)$, for Azotobacter was used method of liquid on Fjodorov medium $\left(10^{2}\right)$, (Anderson 1965). The number of bacteria was determined on soil agar $\left(10^{7}\right)$ (Poshon and Tardievx 1962) and number of fungi on Czapek-Dox medium $\left(10^{4}\right)$, (Scharlau 1999).

All data obtained were processed statistically by StatSoft 'STATISTICA 12.0' program. The results were statistically analyzed according to the two-factor analysis of variance and consequently used Fisher's LSD test, the homogeneity of variance (Excel 2010, DSAASTAT 2014).

\section{RESULTS AND DISCUSSION}

The number and activity of soil microorganisms depends on the properties of the soil, crop grown, cultural practices applied, environmental factors, etc. In this trial, we used the same soil type in organic and conventional production by using different cultivar of beans.

Actinomycetes are active producers of antibiotics and growth stimulators and their products can inhibit or stimulate the other microorganisms.

The number of actinomycetes in this study in the beginning of vegetation period was very high

I: The number of actinomycetes at the beginning and the end of the vegetation period $\left(10^{4} / \mathrm{g}\right.$ soil $)$

\begin{tabular}{lccc}
\hline \multicolumn{1}{c}{ Cultivars } & Conventional & Organic & $\overline{\mathrm{x}}$ \\
\hline Balkan & The number of actinomycetes at the beginning of the vegetation period & \\
Belko & $5.40 \mathrm{a}$ & $4.38 \mathrm{a}$ & 4.89 \\
Dvadesetica & $5.43 \mathrm{a}$ & $4.81 \mathrm{a}$ & 5.12 \\
Maksa & $5.50 \mathrm{a}$ & $4.78 \mathrm{a}$ & 5.14 \\
Slavonac & $5.08 \mathrm{a}$ & $4.18 \mathrm{a}$ & 4.63 \\
Sremac & $5.15 \mathrm{a}$ & $4.56 \mathrm{a}$ & 4.85 \\
Zlatko & $5.53 \mathrm{a}$ & $5.05 \mathrm{a}$ & 5.29 \\
$\overline{\mathbf{x}}$ & $5.42 \mathrm{a}$ & $4.79 \mathrm{a}$ & 5.11 \\
\hline & 5.36 & 5.26 & 5.31 \\
\hline Balkan & The number of actinomycetes at the end of the vegetation period & 5.22 \\
Belko & $5.47 \mathrm{a} \mathrm{b}$ & $4.97 \mathrm{a} \mathrm{b}$ & 4.95 \\
Dvadesetica & $5.13 \mathrm{a} \mathrm{b}$ & $4.78 \mathrm{a} \mathrm{b}$ & 5.53 \\
Maksa & $5.83 \mathrm{a}$ & $5.23 \mathrm{a} \mathrm{b}$ & 4.6 \\
Slavonac & $4.49 \mathrm{~b}$ & $4.71 \mathrm{a} \mathrm{b}$ & 5.53 \\
Sremac & $5.53 \mathrm{a} \mathrm{b}$ & $5.54 \mathrm{a} \mathrm{b}$ & 5.33 \\
Zlatko & $5.72 \mathrm{a} \mathrm{b}$ & $4.91 \mathrm{a} \mathrm{b}$ & 5.45 \\
$\bar{x}$ & $5.41 \mathrm{a} \mathrm{b}$ & $5.49 \mathrm{a} \mathrm{b}$ & 5.23 \\
\hline
\end{tabular}

The different letter represent statistical difference at $\mathrm{P}<0.05$ according to Fisher's test 
in the tested soil but there was not significantly different between the number of actinomycetes in organic and conventional production system in all tested cultivars of beans (Tab. I). At the end of vegetation period number of actinomycetes in soil was greater in conventional production of bean cultivars compared to organic production. The highest number recorded was at cultivar
Dvadesetica (5.83), while the smallest number of actinomycetes was under cultivar Maksa (4.49) in conventional production.

The number of actinomycetes in the soil of organic production was lower, however it is uniform and not significantly different when we compare tested cultivars. (Tab. I).

II: The number of ammonifiers at the beginning and the end of the vegetation period $\left(10^{7} / \mathrm{g}\right.$ soil).

\begin{tabular}{lccc}
\hline \multicolumn{1}{c}{ Cultivars } & Conventional & Organic & $\overline{\mathrm{x}}$ \\
\hline Balkan & The number of ammonifiers at the beginning of the vegetation period & \\
Belko & $9.46 \mathrm{a}$ & $9.43 \mathrm{a}$ & 9.44 \\
Dvadesetica & $8.83 \mathrm{a}$ & $8.94 \mathrm{a}$ & 8.88 \\
Maksa & $8.73 \mathrm{a}$ & $8.65 \mathrm{a}$ & 8.69 \\
Slavonac & $8.69 \mathrm{a}$ & $8.85 \mathrm{a}$ & 8.77 \\
Sremac & $9.06 \mathrm{a}$ & $8.92 \mathrm{a}$ & 8.99 \\
Zlatko & $8.76 \mathrm{a}$ & $9.08 \mathrm{a}$ & 8.91 \\
$\overline{\mathbf{x}}$ & $8.87 \mathrm{a}$ & $8.86 \mathrm{a}$ & 8.87 \\
\hline & 8.92 & 8.96 & 8.94 \\
\hline Balkan & The number of ammonifiers at the end of the vegetation period & 9.07 \\
Belko & $9.25 \mathrm{a} \mathrm{b}$ & $8.89 \mathrm{a} \mathrm{b}$ & 9.09 \\
Dvadesetica & $8.28 \mathrm{a}$ & $9.90 \mathrm{a}$ & 9.15 \\
Maksa & $9.14 \mathrm{a} \mathrm{b}$ & $9.15 \mathrm{a} \mathrm{b}$ & 8.14 \\
Slavonac & $8.15 \mathrm{a}$ & $8.33 \mathrm{~b}$ & 8.54 \\
Sremac & $8.76 \mathrm{a}$ & $8.32 \mathrm{a} \mathrm{b}$ & 8.31 \\
Zlatko & $8.40 \mathrm{a}$ & $9.91 \mathrm{~b}$ & 8.66 \\
$\bar{x}$ & $8.27 \mathrm{a}$ & $9.05 \mathrm{a} \mathrm{b}$ & 8.71 \\
\hline
\end{tabular}

The different letter represent statistical difference at $\mathrm{P}<0.05$ according to Fisher's test.

III: The number of Azotobacter at the beginning and the end of the vegetation period $\left(10^{2} / \mathrm{g}\right.$ soil).

\begin{tabular}{|c|c|c|c|}
\hline Cultivars & Conventional & Organic & $\overline{\mathrm{x}}$ \\
\hline \multicolumn{4}{|c|}{ The number of Azotobacter at the beginning of the vegetation period } \\
\hline Balkan & $4.04 \mathrm{bc}$ & $4.24 \mathrm{abc}$ & 4.14 \\
\hline Belko & $4.30 \mathrm{a}$ & $4.04 \mathrm{~b} \mathrm{c}$ & 4.17 \\
\hline Dvadesetica & $4.09 \mathrm{abc}$ & $4.03 \mathrm{~b} \mathrm{c}$ & 4.06 \\
\hline Maksa & $4.01 \mathrm{c}$ & $4.24 \mathrm{a} b$ & 4.13 \\
\hline Slavonac & $4.09 \mathrm{abc}$ & $4.17 \mathrm{abc}$ & 4.13 \\
\hline Sremac & $4.01 \mathrm{c}$ & $4.18 \mathrm{abc}$ & 4.09 \\
\hline Zlatko & $4.25 \mathrm{ab}$ & $4.19 \mathrm{abc}$ & 4.22 \\
\hline$\underline{\bar{x}}$ & 4.12 & 4.16 & 4.14 \\
\hline \multicolumn{4}{|c|}{ The number of Azotobacter at the end of the vegetation period } \\
\hline Balkan & $3.75 \mathrm{ab}$ & $4.19 \mathrm{a}$ & 5.85 \\
\hline Belko & $4.04 \mathrm{a}$ & $4.17 \mathrm{a}$ & 4.12 \\
\hline 20-tica & $3.50 \mathrm{ab}$ & $3.93 \mathrm{ab}$ & 3.72 \\
\hline Maksa & $3.70 \mathrm{ab}$ & $4.47 \mathrm{a}$ & 4.09 \\
\hline Slavonac & $3.97 \mathrm{ab}$ & $4.24 \mathrm{a}$ & 4.12 \\
\hline Sremac & $2.92 \mathrm{~b}$ & $4.48 \mathrm{a}$ & 3.7 \\
\hline Zlatko & $3.96 \mathrm{ab}$ & $4.03 \mathrm{a}$ & 3.99 \\
\hline $\bar{x}$ & 3.69 & 4.22 & 3.95 \\
\hline
\end{tabular}

The different letter represent statistical difference at $\mathrm{P}<0.05$ according to Fisher's test. 
The number of ammonifiers was not significantly different between organic and conventional production of beans at the beginning of the growing season. (Tab. II).

At the end of the growing season the highest number reached cultivar Sremac (9.91) in organic production, while the smallest number in organic production reached cultivar Slavonac (8.32). The total number of ammonifiers was higher in organic production than in conventional production. (Tab. II).

The amount of nitrogen that Azotobacter absorb from the air depends on the conditions prevailing in the soil. Number of Azotobacters tends to increase in plant rhizosphere, which is rich in organic matter provided by plant roots. In organic production

IV: The number of bacteria at the beginning and the end of the vegetation period $\left(10^{7} / \mathrm{g}\right.$ soil).

\begin{tabular}{lccc}
\hline & Cultivars & Organic & $\overline{\mathrm{x}}$ \\
\hline & The number of bacteria at the beginning of the vegetation period & \\
\hline Balkan & $9.45 \mathrm{a} \mathrm{b}$ & $9.70 \mathrm{a}$ & 9.57 \\
Belko & $8.94 \mathrm{a} \mathrm{b}$ & $9.23 \mathrm{a} \mathrm{b}$ & 9.09 \\
Dvadesetica & $8.79 \mathrm{~b}$ & $8.71 \mathrm{~b}$ & 8.75 \\
Maksa & $8.80 \mathrm{~b}$ & $9.09 \mathrm{a} \mathrm{b}$ & 8.95 \\
Slavonac & $9.18 \mathrm{a} \mathrm{b}$ & $8.89 \mathrm{~b}$ & 9.03 \\
Sremac & $8.98 \mathrm{a} \mathrm{b}$ & $9.18 \mathrm{~b} \mathrm{a}$ & 9.08 \\
Zlatko & $9.30 \mathrm{a} \mathrm{b}$ & $8.78 \mathrm{~b}$ & 9.03 \\
$\overline{\mathbf{x}}$ & 9.07 & 9.08 & 9.075 \\
\hline & The number of bacteria at the end of the vegetation period & 8.65 \\
\hline Balkan & $8.30 \mathrm{a} \mathrm{b}$ & $9.00 \mathrm{a} \mathrm{b}$ & 8.22 \\
Belko & $8.01 \mathrm{a} \mathrm{b}$ & $8.43 \mathrm{a} \mathrm{b}$ & 8.15 \\
Dvadesetica & $7.21 \mathrm{~b}$ & $9.08 \mathrm{a}$ & 8.83 \\
Maksa & $8.69 \mathrm{a} \mathrm{b}$ & $8.97 \mathrm{a} \mathrm{b}$ & 8.35 \\
Slavonac & $8.04 \mathrm{a} \mathrm{b}$ & $8.67 \mathrm{a} \mathrm{b}$ & 8.39 \\
Sremac & $8.30 \mathrm{a} \mathrm{b}$ & $8.47 \mathrm{a} \mathrm{b}$ & 8.57 \\
Zlatko & $8.18 \mathrm{a} \mathrm{b}$ & $8.97 \mathrm{a} \mathrm{b}$ & 8.45 \\
$\bar{x}$ & 8.11 & 8.8 & \\
\hline
\end{tabular}

The different letter represent statistical difference at $\mathrm{P}<0.05$ according to Fisher's test.

V: The number of fungi at the beginning and the end of the vegetation period $\left(10^{4} / \mathrm{g}\right.$ soil)

\begin{tabular}{|c|c|c|c|}
\hline Cultivars & Conventional & Organic & $\overline{\mathrm{x}}$ \\
\hline \multicolumn{4}{|c|}{ The number of fungi at the beginning of the vegetation period } \\
\hline Balkan & $4.98 \mathrm{a}$ & $5.45 \mathrm{ab}$ & 5.22 \\
\hline Belko & $4.17 \mathrm{~b}$ & $5.05 \mathrm{ab}$ & 4.61 \\
\hline Dvadesetica & $5.05 \mathrm{a}$ & $4.78 \mathrm{ab}$ & 4.91 \\
\hline Maksa & $4.90 \mathrm{a}$ & $5.03 \mathrm{~b}$ & 4.97 \\
\hline Slavonac & $4.99 \mathrm{a}$ & $5.40 \mathrm{ab}$ & 5.19 \\
\hline Sremac & $4.75 \mathrm{ab}$ & $5.51 \mathrm{a}$ & 5.12 \\
\hline Zlatko & $4.35 \mathrm{ab}$ & $4.79 \mathrm{ab}$ & 4.57 \\
\hline$\overline{\mathrm{x}}$ & 4.75 & 4.65 & 4.7 \\
\hline \multicolumn{4}{|c|}{ The number of fungi at the end of the vegetation period } \\
\hline Balkan & $4.61 \mathrm{abc}$ & $3.87 \mathrm{c}$ & 4.24 \\
\hline Belko & $4.61 \mathrm{ab}$ & $4.96 \mathrm{ab}$ & 4.78 \\
\hline Dvadesetica & $4.87 \mathrm{abc}$ & $4.75 \mathrm{abc}$ & 4.81 \\
\hline Maksa & $4.03 \mathrm{~b} \mathrm{c}$ & $4.75 \mathrm{abc}$ & 4.39 \\
\hline Slavonac & $4.67 \mathrm{abc}$ & $4.90 \mathrm{abc}$ & 4.79 \\
\hline Sremac & $4.61 \mathrm{abc}$ & $4.26 \mathrm{abc}$ & 4.43 \\
\hline Zlatko & $4.37 \mathrm{abc}$ & $5.14 \mathrm{a}$ & 4.75 \\
\hline $\bar{x}$ & 4.54 & 4.67 & 4.56 \\
\hline
\end{tabular}

The different letter represent statistical difference at $\mathrm{P}<0.05$ according to Fisher's test. 
the number of Azotobacter was increased, but this increase was not statisticly significant between all cultivars in the begininig of growing season (Tab. III). In conventional production exist difference, statistically the lowest number of Azotobacter reached cultivar Maksa (4.01) while statistically the highest number of Azotobacter reached cultivar Belko (4.30).

At the end of the growing season the number of Azotobacter under conventional and organic soil was variable in all tested cultivas, with the organic production contributed significantly to the increase in the number of Azotobacter (Tab. III).

The total number of bacteria is used as an indicator of potential soil fertility and it is higher in soil with more organic matter, neutral with good a water-air regime (Jarak and Colo 2007).

In this study, the average number of bacteria was higher at the beginning of the growing season of beans compared to the end and the highest in the rhizosphere cultivars Balkan. At the beginning of the growing season, there was high total number

of bacteria in the soil where the beans were grown in organic production without significant differences to the conventional production.

The cultivar Balkan (Tab. IV) recorded significantly the highest total number of bacteria in the soil in organic production (9.70) and also in conventional production (9.45).

At the end of the growing season, the lowest number has shown cultivar Dvadesetica in conventional production (7.21), while the same cultivar in organic production has shown the highest number of bacteria (9.08). Organic production has shown influence and statistically significant increase in the total number of bacteria in the soil than conventional one (Tab. IV).

The number of fungi in this study did not change significantly during the growing season. The reduction and increase of the number depending on the way of production was not statistically significant, and the average of the highest number of fungi was found in cultivar Balkan at the beginning of the growing season.

The number of fungi was not significantly different between organic and conventional production as well as between cultivars at the end of vegetation period, but exist significantly difference comparing to beginning of the growing season (Tab. V). In organic production the highest number of fungi was in the soil in cultivar Zlatko (5.14) and the smallest in cultivar Balkan (3.87) at the end of vegetation period.

As with previous groups of microorganisms, number of fungi was higher in soil under organic beans (Tab. V).

Studies of the microbial inoculation in the production of beans have shown that nodulation rate, nitrogen content in seed, crop yield and soil microbial activities depend on soil properties, bean cultivar and the properties of inoculants (Hungria et al., 1999; Vargas and Mendes, 2000). Further, the results of Milić et al., (1999), Jarak et al., (2005) and Marinković et al., (2008) showed that the application of effective strains of nodular bacteria in the production of beans increases the soil microbial activity and facilitates plant growth and development.

\section{CONCLUSION}

The highest number of actinomycetes within the conventional production was recorded in cultivar Dvadesetica, while minimum was found in cultivar Maksa. The number of actinomycetes in the soil of organic production was lower. However it was uniform and not significantly different when we examine the observed cultivars.

The highest number of ammonifires was in cultivar Sremac in organic production, while the smallest number in organic production was in cultivar Slavonac. The total number of ammonifires was higher in organic production than in conventional one at the end of the growing season.

When testing the number of microorganisms, organic production had positive influence on the increase of Azotobacter at the end of the growing season.

The highest number of bacteria in organic production was in cultivar Dvadesetica, while the same cultivar in conventional production recorded the lowest number of bacteria at the end of vegetation period. Organic production has influenced the significant increase in the total number of bacteria in the soil if compared to the conventional production.

Organic production has influenced the significant increase in the total number of bacteria in the soil if compared to the conventional production.

The highest number of fungi in the organic production was in the soil in cultivar Zlatko, and the smallest in cultivar Balkan. Number of fungi was higher in soil at organic beans. The total number of evaluated microorganisms was higher in organic production which positively affects the fertility in the soil in comparison to conventional production. 


\section{REFERENCES}

ANDERSON, G. R. 1965. Ecology of Azotobacter in soil of the Palouse region. I: Occurrence. Soil Sci., 86: 57-65. BLOEM, J., HOPKINS, W. D. and BENEDETTI, A. 2006. Microbiological Methods for Assessing Soil Quality. $1^{\text {st }}$ Edition. Wallingford: CABI Publishing.

GEORGE, T. and SINGLETON, P. W. 1992. Nitrogen Assimilation Traits and Dinitrogen Fixation in Soybean and Common Bean. Agronomy Journal, 84, 1020-1028.

HUNGRIA, M., VARGAS, M., CAMPO, R. et. al. 1999. The Brazilian Experience with the Soybean (Glycine max) and Common Bean (Phaseolus vulgaris) Symbioses F.O. In: PEDROSA, F. O. et al. (Eds.). Nitrogen Fixation: From Molecules to Crop Productivity. Proceedings of the $12^{\text {th }}$ International Congress on Nitrogen Fixation, Foz do Iguaçu, Paraná, Brazil, September 12-17, 1999, pp. 515-518.

JARAK, M. and COLO, J. 2007. Microbiology of Soils [in Serbian Mikrobiologija zemlijista]. University of Novi Sad, Faculty of Agriculture.

JARAK, M. and ĐJURIĆ, S. 2006. Laboratory Exercises in Microbiology [in Serbian: Laboratorijske vezbe u Mikrobiologiji]. University of Novi Sad, Faculty of Agriculture.

JARAK, M., ZDRAVKOVIĆ, M., ĐURIC, S., et. al. 2005: Response of beans to inoculation and fertilizers. In: Proceedings of the 8th International Symposium on Interdisciplinary Regional Research (Hungary-Romania-Serbia and Montenegro). [CD-ROM]. 19-21 April 2005, Szeged, Hungary. Sect. 2-Ecology and Environmental Protection, EEP22.

KRASILJNIKOV, N. A. 1965. Biology certain groups of actinomycetes. Science Moskva.

MARINKOVIĆ, J. 2006. Effect of Rhizobium legominusarum bv.phaseoli [in Serbian: Uticaj Rhizobium legominusarum bv.phaseoli]. Master thesis. University of Novi Sad, Faculty of Agriculture.

MARINKOVIC, J., VASIC, M. and JARAK, M. 2008. Effect of bean inoculation with Rhizobium leguminosarum bv. phaseoli on pod and grain number and grain mass. In: Book of Abst. Integrating legume science and crop breeding. 27-28. 11., Novi Sad, Srbija.

MILIC, V., MRKOVACKI, N., VASIC, M., et. al. 1999. Symbiotic effectiveness of bean genotypes. Soil and Plant, 48(1): 43-48.

NEERU, N. and VASUDEVA, M. 2007. Enviromental microbiology: Terrestrial Envionment. CCS Haryana Agricultual Univesity Hisar, Departman of microbiology.

NLEYA, T., WALLERY, F. and VANDENBERG, A. 2001. Response of four common bean cultivars to granular inoculants in a short-season dryland production system. Canadian Journal of Plant Science, 81(3): 385-390.

POCHON, J. and TARDIEUX, P. 1962. Techniques d'analyse en microbiologie du sol. St-Mandé: Éditions de la Tourelle.

SHANNON, D., SEN, A. M. and JOHNSON, D. B. 2002. A comparative study of the microbiology of soils managed under organic and conventional regimes. Soil Use and Management, 18(Supplement s1): 274-283.

SCHARLAU MICROBIOLOGY. 1999. Handbook of Microbiological Culture media. Barcelona: Scharlau.

VARGAS, M. and MENDES, C. 2000. Response of field-grown bean (Phaseolus vulgaris L.) to Rhizobium inoculation and nitrogen fertilization in two Cerrados soils. Biol. Fert. Soils, 32: 228-233.

WANI, S. P., RUPELA, O. P. and LEE, K. K 1994. BNF Tehnology for Sustanible Agriculture in the Semi-Arid tropics. In: Transactions of the 15th World Congress of Soil science. 10-16 July 1994, Acapulco, Mexico. Vol. 4a, commission III symposia, pp. 245-262.

Contact information

Bojana Petrović: petrovic_bojana@hotmail.com

Simonida Đurić: simonida@polj.uns.ac.rs

Mirjana Vasić: vasicka008@gmail.com

Vesna Tunguz: vesna.tunguz@gmail.com

Robert Pokluda: robert.pokluda@mendelu.cz 